\title{
Improved testing procedures to assess the physical and mechanical properties of ceramic blocks
}

Ailton Freire ${ }^{1}$, Guilherme Parsekian ${ }^{2}$, Adriana Baptista ${ }^{2}$, Fernando Fonseca ${ }^{3}$

\footnotetext{
${ }^{1}$ Instituto Federal do Piauí, Departamenteo de Engenharia Civil, Av. Pedro Freitas, 1020, CEP 64010-000, Teresina, PI, Brasil

${ }^{2}$ Universidade Federal de São Carlos, Departamento de Engenharia Civil, Rod. Washington Luís km 235 - SP-310, CEP 13565-905, São Carlos, SP, Brasil

${ }^{3}$ Brigham Young University, Civil and Environmental Engineering, 430 Engineering Building, Provo, UT, 84042, USA

e-mail: ailton.freire@ifpi.edu.br, parsekian@ufscar.br, adrianacmbaptista@gmail.com, fonseca@byu.edu
}

\begin{abstract}
In Brazil, ceramic blocks have a significant share of the masonry construction market. Thus, an experimental testing program was devised to determine the physical and mechanical properties of ceramic blocks from different regions of Brazil. The experimental program included blocks from five Brazilian states and ten different producers, and the properties studied were absorption, material density, efflorescence, abrasion, compressive strength, and resistance towet-dry cycles. The purpose of determining these material properties is to set guidelines to standardize the performance of same-geometry blocks. The material density test method and the wet- and dry cycle test method are being proposed as new tests and are not usually specified in international codes. The objective of the wet and dry cycle test is to determine a durability parameter for blocks that are not subjected to freeze-thaw cycles. The analysis of the results identified important relationship between these properties.
\end{abstract}

Keywords: masonry, clay, ceramic blocks, test in blocks.

\section{INTRODUCTION}

There are several applications of ceramic materials: from science to technology, to industry [1-3]. Industrial application includes the manufacturing of ceramic blocks for use in masonry, which represents $80 \%$ of masonry construction in Brazil [4].

Structural masonry has been proved to be a competitive building system for housing construction throughout Brazil [5]. Structural masonry construction has several advantages, the main one being the fact that one element, masonry, fulfills several functions [6]. Another advantage of masonry is its durability, obtained from the proper selection of materials [7]. The main masonry element is either a concrete or a ceramic block; ceramic blocks are produced with fine-grained, non-metallic, and inorganic iron or alkali rich clays.

The properties of ceramic products depend primarily on the elements of their composition [8, 9] and the clay composition [10-12]. In addition, the maturation time and the forming process are fundamental for the ceramic material to acquire the structural shape and desirable characteristics of the final product [13].

Locally, ceramic blocks and bricks for structural and non-structural masonry must meet the physical and mechanical characteristics specified in the ABNT NBT 15.270 [14]. The dry mass, water absorption index, compressive strength, initial absorption index, efflorescence properties specifications and test method in this Brazilian standard are like those in the ASTM C-67 [15]. Recently, the Brazilian code also adopted a test method to evaluate the density of the clay block material. The intention of the code is to allow performance tests in masonry elements built with blocks from a specific producer to serve to certify masonry elements built with blocks from a different producer. This is possible if both the block geometry and material density are approximately the same.

Internationally, clay block durability is usually related to its absorption index and resistance to freezethaw cycles [7]. However, these properties are not adequate to estimate clay block durability in tropical and semi-tropical regions. In these regions, the durability may be related to the resistance to wet and dry cycles 
and to the block superficial abrasion resistance. In this paper, results from a proposed wet and dry cycle test method and abrasion tests are reported.

Since the absorption index is an important characteristic of porous materials [14], the analyses relate the absorption index to the compressive strength, density, efflorescence and durability.

The masonry compressive strength is a factor that largely depends on the block compressive strength [16-18]. This is one of the most important characteristic of structural masonry [19-21]. Other properties with significant relevance to ceramic blocks are: density, which is associated with the sound insulation [22, 23]; thermal conductivity [24, 25]; efflorescence, which even if it is an aesthetic problem, can cause problems in the structure if not properly treated [26-28]; and abrasion resistance. The last property is more important for façade masonry walls (uncoated), which may have their appearance damaged during cleaning procedures [29] or from by rain and wind.

The investigation herein described analyzed the properties of Brazilian ceramic blocks, from different regions of the country, that had their physical and mechanical tested in the same research program. In addition, the article presents the relationships between the investigated properties and describes proposed new and modified test procedures. The main goal of the investigation was to devise a set of tests that would allow complete characterization of Brazilian ceramic blocks such that future comparisons with ceramic blocks from different producers would be possible and to analyze the test procedures proposed.

\section{MATERIALS AND METHODS}

This research evaluated the test procedures presented in ABNT NBR 15270:2017 [14], such as hot and coldwater absorption, initial absorption, paraffin density and compressive strength, and efflorescence. The research herein reported allowed the inclusion of some of these test that were not specified in the previous version of this standard code. Other test procedures are reported, such as paraffin-free density, abrasion resistance and resistance to wet and dry cycles. These new test procedures allowed to decide the best practices and to recommend it to the code during its discussion phase.

The experimental program was carried out to evaluate ceramic block test procedures is summarized in table 1 . The procedures were repeated for the blocks of each producer. Although some of these procedures are now incorporated into ABNT NBT 15270 [14], the information in table 1 refers to the standard code that were the base reference to the experimental program.

Table 1: Summary of the experimental program

\begin{tabular}{l|c|c}
\hline Property & Test Method & No. of specimens \\
\hline Cold water absorption & & 6 \\
\cline { 1 - 1 } Hot water absorption & ASTM C67 & 6 \\
\cline { 1 - 1 } Initial absorption & & 6 \\
\hline Density without paraffin & Adapted from ABNT NBR & 6 \\
\cline { 3 - 3 } Paraffin with density & $10838: 1988$ & 6 \\
\hline Efflorescence (Prism extracted from block) & Franco (2012) & 6 \\
\hline Efflorescence (Whole Block) & ASTM C67 & \multicolumn{2}{|c}{10} \\
\cline { 1 - 1 } Abrasion resistance & Adapted from ABNT NBR & 5 \\
\hline \multirow{2}{*}{ Wet and dry cycle resistance } & $13818: 1997$ & \multirow{2}{*}{3} \\
\hline Compressive strength & Adapted from ABNT NBR & 13 \\
\hline
\end{tabular}

The ceramic blocks used, donated by the National Ceramic Industry Association (ANICER), came from ten different producers from the states of São Paulo, Minas Gerais, Rio de Janeiro, Rio Grande do Norte and Pará. A set of 150 units was received from each producer.

Structural hollow wall blocks, shown in Figure 1A; non-structural blocks with vertical hollows, shown in Figure 1B; and non-structural blocks with horizontal hollows, shown in Figure 1C; were tested. 


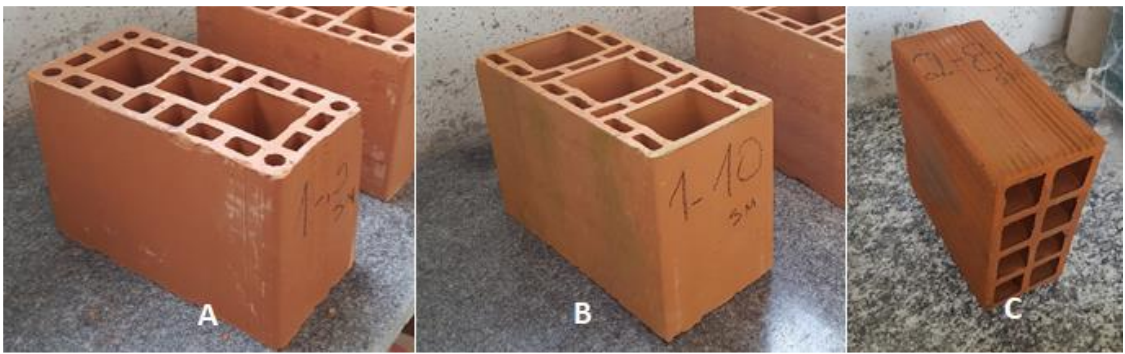

Figure 1: Types of blocks tested in research.

\subsection{Hot and cold water absorption test}

Absorption tests in hot and cold water were conducted according to ASTM C67 [15], which specifies placing the specimen into boiling water for two hours or placing the specimen into room-temperature water for 24 hours.

In both test methods, the procedure started with placing each block for 48 hours inside the oven, determining the dry mass, followed by complete immersion of the blocks for 2 hours in hot water or 24 hours in room temperature water. After the specimens are removed from water, the excess water is removed with a damp cloth and the final wet mass of each specimen determined.

\subsection{Initial absorption test}

These tests were conducted according to ASTM C67 [15]. The first step was to determine the geometric dimensions of each block. The blocks were then submerged into water for 24 hours and then weighed in a saturated condition on a 1-g precision scale and on a hydrostatic scale to determine their saturated and hydrostatic weight.

To calculate the initial absorption index, the blocks were oven dried for 24 hours and then their dry mass determined. The blocks where then placed whit their faces 3-mm deep into a tray filled with water for 60 seconds. The specimens were then dried using a damp cloth and weighed on the 1-g precision scale. The block net area was also calculated from these testing.

\subsection{Density test}

The density test was conducted with and without paraffin with the procedure adapted from ABNT NBR 10.838 [30]. For the paraffin-free tests, $5 \times 5 \mathrm{~cm}$ prisms were cut from the block face shells, oven-dried for 24 hours, and weighed. The prisms were then immersed into water for 24 hours. After, the excess water was removed, and the specimens weighed again using a hydrostatic scale.

For the paraffin test, the prismatic specimens are oven-dried for 24 hours, and weighted. After, the specimen was immersed in melted paraffin to seal the specimen and prevent water absorption. The weight of the specimens is then determined using a hydrostatic scale.

From this data it was possible to calculate the volume and apparent specific mass of each specimen.

\subsection{Efflorescence test}

The efflorescence tests were conducted using two procedures: the Franco method [31] and that of the ASTM C67 [15]. In the first procedure, six $2-\mathrm{cm}$ wide by $20-\mathrm{cm}$ high prisms were extracted from six blocks from each producer as shown in Figure 2. These prisms were incubated for 24 hours and then placed for 5 days in cups (200 ml capacity) with distilled water to a depth of $5 \mathrm{~cm}$. The cups were covered using a rubber membrane and placed in a ventilated environment. 


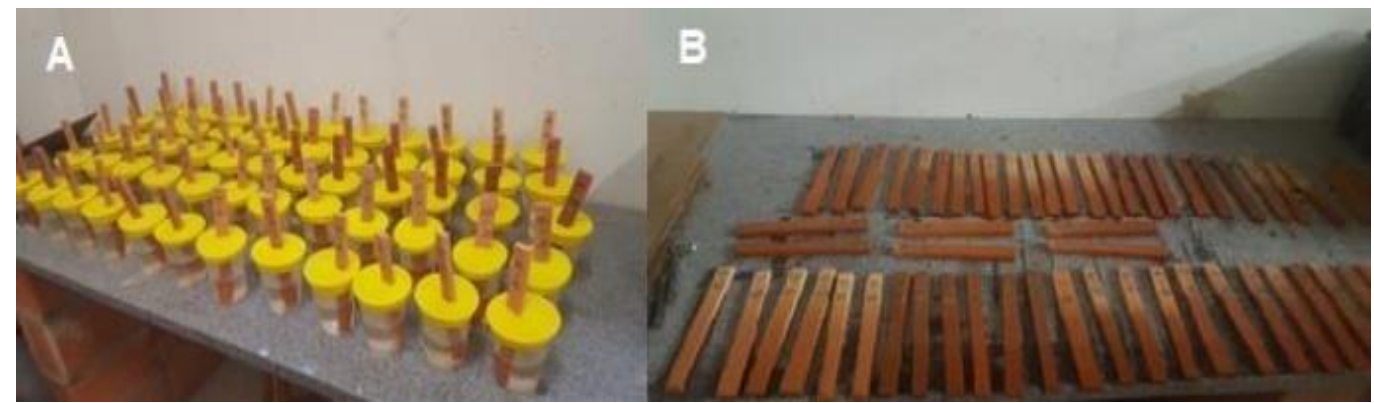

Figure 2: A) ready samples and B) extracted prisms

The specimens were supervised daily to refill the water, if necessary, and to identify possible cases of efflorescence, especially on the parts of the prism exposed to ventilation. After the 5 days period, the samples were removed from the cups and placed in an oven for 24 hours, after which, they were visually inspected for efflorescence.

The test according to ASTM C67 [15] was conducted over a 7-day period on whole ceramic blocks. Ten units were used; 5 units were placed on a tray filled with $2.54 \mathrm{~cm}$ of water and $5.08 \mathrm{~cm}$ apart and the water level was maintained constant. The other 5 units were placed in the same environment but without water contact.

\subsection{Abrasion resistance test}

The test was conducted based on the specifications of ABNT NBR 13818 [32] but adapted for ceramic blocks. Five $11 \times 2.8 \mathrm{~cm}$ prisms were cut from the block face shell. These prisms were placed into an abrasion testing machine, which consists of a rotating disc and a specific abrasive material. Each specimen is tested for 150 disc-rotations. The specimen experiences abrasion in the form of a cavity. The cavity is then measured with the aid of a caliper and analyzed according to the removed volume of material using the table provided in the standard.

\subsection{Wet and dry cycle test}

The test procedure described in ABNT NBR 13554 [33], was adapted for ceramic blocks. This test was conducted using three specimens, named CP1, CP2 and CP3. Specimen CP1 was used to calculate moisture and volume variations, and specimen $\mathrm{CP} 2$ and $\mathrm{CP} 3$ were used to calculate mass loss.

The specimens were placed inside an oven for 24 hours, then weighed and measured. After they were submerged into water for 5 hours. Specimen CP1 was dried with a cloth, weighed, and measured. Each face of specimen CP2 and CP3 was brushed with 20 vertical strokes and then brushed with another 4 strokes using a wire brush and a force of $15 \mathrm{~N}$. For the application force to be constant and reach the value of $15 \mathrm{~N}$ required by the standard, the specimens were placed on a scale during brushing maintaining the $1.5 \mathrm{~kg}$ reading in the scale. The operation was repeated for 6 cycles. At the end of the last cycle, the specimens were placed inside an oven until constant mass was reached.

\subsection{Compressive strength test}

The test was conducted using the methodology presented in ABNT NBR 15270 [14]. A set of 13 specimens from each producer was tested. The first step of the test was to cap the samples, to level the top and bottom faces of the blocks, using a water-moistened cementitious paste prepared over a plastic film, as shown in Figure 3A (a transparent plastic film is present over the granite top). The samples were placed on top of the paste, as shown in Figures 3B and 3C. The process was repeated for the other face of the block. 


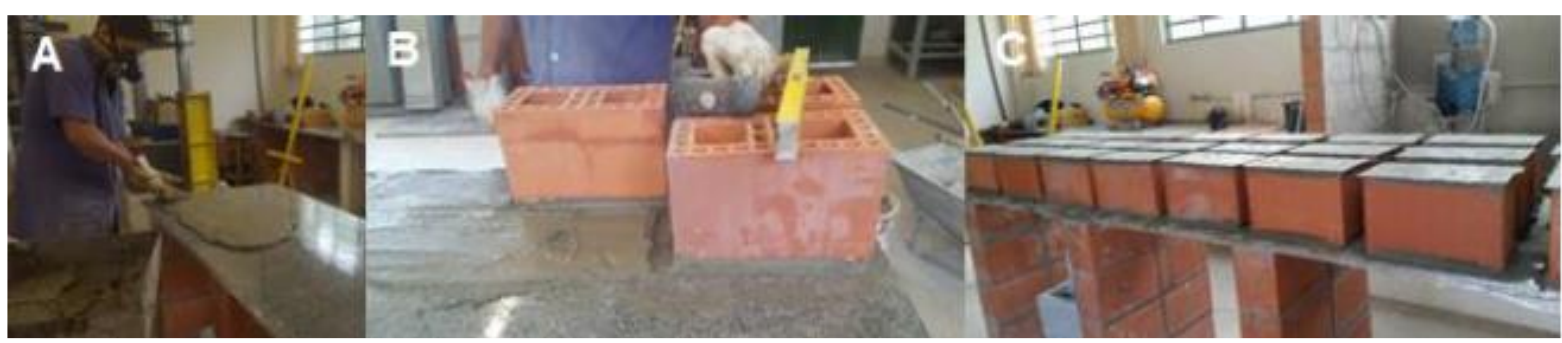

Figure 3: A) Mortar preparation, B) block levelling and C) capped blocks.

After the cap dried, the samples were immersed in water for 6 hours. The saturated specimens were then tested to compression loading.

\section{RESULTS AND DISCUSSIONS}

The following section presents the results from the tests and a discussion highlighting the results that can be used consistently to characterize Brazilian ceramic blocks.

\subsection{Hot and cold water absorption test and initial absorption test}

The hot and cold water absorption test results are presented in table 2. The results have a low dispersion. Although the sample from producer 09 have a higher dispersion value when compared to the other samples, this value is still very low, which indicates similarity among the blocks produced by all producers. In addition, the blocks from all producers met the established range of $8 \%$ to $22 \%$, specified by the Brazilian standard, except blocks from producers 03 and 08.

Table 2: Absorption Index Results

\begin{tabular}{|c|c|c|c|c|c|c|c|}
\hline \multirow{3}{*}{ Producer } & \multirow{3}{*}{ Block type } & \multicolumn{4}{|c|}{ Absorption Index } & \multirow{3}{*}{$\begin{array}{l}\text { Saturation } \\
\text { coefficient }\end{array}$} & \multirow{3}{*}{$\begin{array}{c}\text { Initial absorption } \\
\text { index } \\
\text { (average) } \\
\left(\mathrm{g} / 194 \mathrm{~cm}^{2} / \mathrm{min}\right)\end{array}$} \\
\hline & & \multicolumn{2}{|c|}{ Cold water } & \multicolumn{2}{|c|}{ Hot water } & & \\
\hline & & Average & $\begin{array}{l}\text { Coefficient of } \\
\text { Variation }(\%)\end{array}$ & Average & $\begin{array}{l}\text { Coefficient of } \\
\text { Variation }(\%)\end{array}$ & & \\
\hline 01 & Structural & 17.8 & 1.29 & 17.5 & 1.49 & 1.02 & 20.0 \\
\hline 02 & Structural & 13.9 & 3.17 & 14.8 & 1.76 & 0.94 & 28.7 \\
\hline 03 & Structural & 22.7 & 0.70 & 22.8 & 0.92 & 1.00 & 33.1 \\
\hline 04 & Structural & 14.3 & 1.33 & 15.0 & 1.87 & 0.95 & 29.5 \\
\hline 05 & Structural & 15.2 & 1.05 & 15.9 & 2.45 & 0.96 & 16.1 \\
\hline 06 & Structural & 14.0 & 3.43 & 15.3 & 3.01 & 0.92 & 21.3 \\
\hline 07 & Structural & 17.5 & 2.23 & 17.9 & 1.79 & 0.98 & 27.4 \\
\hline 08 & Non-structural & 7.8 & 3.85 & 9.6 & 5.52 & 0.81 & 9.5 \\
\hline 09 & Non-structural & 16.7 & 6.89 & 17.4 & 6.78 & 0.96 & 16.3 \\
\hline 10 & Non-structural & 13.6 & 2.43 & 13.6 & 3.90 & 1.00 & 15.1 \\
\hline
\end{tabular}

There is little difference between the results from the tests performed in cold water and hot water. Unlike the other blocks, the blocks from producer $01 \mathrm{had}$, on average, higher absorption in cold water than that in hot water and the blocks from producer 10, which had exactly the same absorption values in hot and cold water.

The results from this work for the saturation coefficient, which vary between 0.81 and 1.02 , are higher than the maximum value allowed for the saturation coefficient for cold regions specified in the American standard (ASTM) [15] which is 0.80 or in the Canadian standard (CSA) [34] which is 0.78 .

The two-sample statistical analysis of variance $\mathrm{z}$ conducted to compare the cold and hot water average results indicates that the averages are not statistically different for $55.5 \%$ of the cases for a significance level 
of 0.05 , i.e., the trials are similar for more than half of the blocks analyzed.

When analyzing the initial absorption results, that for the blocks from producer 03 has a value greater than $30 \mathrm{~g} / 194 \mathrm{~cm}^{2} / \mathrm{min}$, which may impair the adhesion of substrates to these blocks [35, 36]. In addition, the non-structural block from all producers had initial absorption values below $20 \mathrm{~g} / 194 \mathrm{~cm}^{2}$, and only the structural block from producer 05 had an absorption below this value.

\subsection{Density test}

The results of the density tests with and without paraffin are presented in Table 3.

Table 3: Density of prisms extracted from ceramic blocks.

\begin{tabular}{|c|c|c|c|c|c|c|}
\hline \multirow[b]{2}{*}{ Producer } & \multirow[b]{2}{*}{ Block type } & \multicolumn{2}{|c|}{ Without paraffin $\left(\mathrm{g} / \mathrm{cm}^{3}\right)$} & \multicolumn{2}{|c|}{ With paraffin $\left(\mathrm{g} / \mathrm{cm}^{3}\right)$} & \multirow{2}{*}{$\begin{array}{c}\text { Difference } \\
(\%)\end{array}$} \\
\hline & & Average & $\begin{array}{l}\text { Coefficient of } \\
\text { Variation }(\%)\end{array}$ & Average & $\begin{array}{l}\text { Coefficient of } \\
\text { Variation }(\%)\end{array}$ & \\
\hline 01 & Structural & 1.78 & 1.12 & 1.95 & 5.64 & 9.49 \\
\hline 02 & Structural & 1.91 & 0.52 & 1.88 & 3.19 & -1.43 \\
\hline 03 & Structural & 1.65 & 0.60 & 1.71 & 6.43 & 4.11 \\
\hline 04 & Structural & 1.88 & 0.53 & 1.98 & 3.53 & 5.31 \\
\hline 05 & Structural & 1.81 & 0.55 & 2.03 & 2.46 & 12.21 \\
\hline 06 & Structural & 1.86 & 0.00 & 1.99 & 1.50 & 6.88 \\
\hline 07 & Structural & 1.80 & 0.00 & 2.04 & 5.39 & 13.01 \\
\hline 08 & Non-structural & 2.00 & 1.00 & 2.10 & 1.90 & 4.60 \\
\hline 09 & Non-structural & 1.79 & 1.67 & 1.91 & 5.75 & 6.87 \\
\hline 10 & Non-structural & 1.91 & 0.52 & 2.06 & 2.43 & 7.89 \\
\hline
\end{tabular}

Paraffin-free prisms have lower densities than paraffin covered prisms except for the prisms from the blocks of producer 02 (with similar results). The prisms from the blocks from producer 07 have the highest density increase from paraffin-free to paraffin-covered tests.

The results from the test performed with paraffin present larger deviations than those from paraffin-free tests. This higher dispersion may be due to the application of paraffin, which in some cases required two or more layers to fully cover the specimen.

Figure 4 shows the results of the paraffin-free density tests performed on prisms taken from the block face shells and density of the entire block. The results show that there is very little difference between the values obtained using the entire block and that using the prisms. 


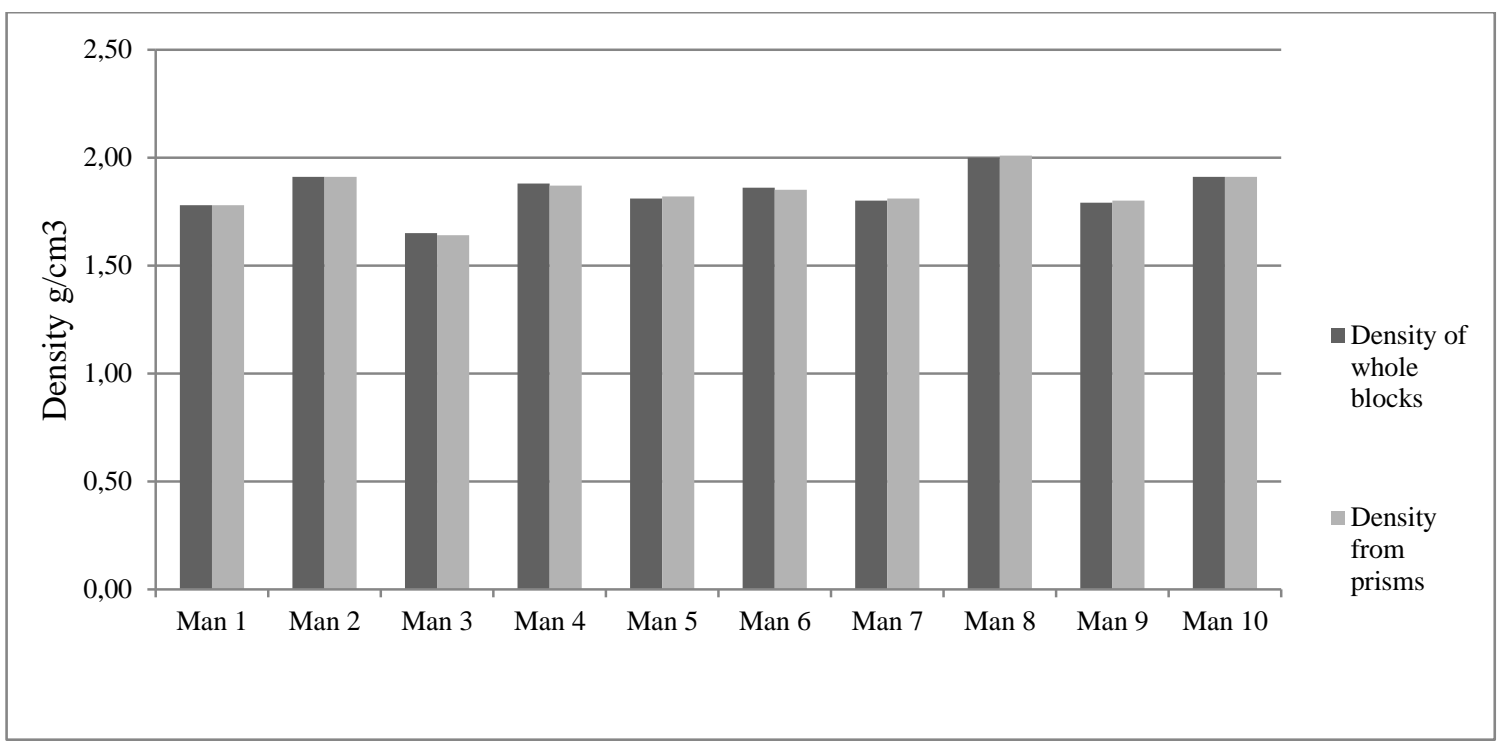

Figure 4: Density of whole blocks and density from prisms.

An ANOVA analysis was conducted between the averages of the paraffin-free and paraffin-covered tests, and there is statistical evidence to suggest that the mean density of the paraffin-free samples is different from the mean density of the paraffin-covered samples, for a significance level of 0.05 .

\subsection{Efflorescence test}

The blocks tested for efflorescence using the Franco method [31] showed no manifestation of efflorescence. When the tests were conducted according with ASTM C67 [15], the blocks from three producers demonstrated efflorescence potential and all blocks from producers 02 and 06, and two specimens from producer 10.

Although the Franco test method [31] is faster than that of the ASTM C67 [15], it has more steps during preparation of the samples and thus is more labor intensive.

\subsection{Abrasion resistance test}

The results for the abrasion resistance test, i.e., the cavity length values and the volume of material lost during the test, are presented in Table 4; the standard deviations are also presented.

Table 4: Abrasion Resistance Results.

\begin{tabular}{c|c|c|c|c|c}
\hline \multirow{2}{*}{ Manufacture } & \multirow{2}{*}{ Block type } & \multicolumn{2}{|c|}{ Cavity $(\mathbf{m m})$} & \multicolumn{2}{c}{ Volume $\left.\mathbf{m m}^{\mathbf{3}}\right)$} \\
\cline { 3 - 6 } & & Average & $\begin{array}{c}\text { Coefficient of } \\
\text { Variation }(\%)\end{array}$ & Average & $\begin{array}{c}\text { Coefficient of } \\
\text { Variation }(\%)\end{array}$ \\
\hline 01 & Structural & 52.85 & 5.01 & 1415.18 & 17.90 \\
\hline 02 & Structural & 43.01 & 4.78 & 718.84 & 15.06 \\
\hline 03 & Structural & 64.72 & 5.88 & 2856.53 & 18.61 \\
\hline 04 & Structural & 46.66 & 2.07 & 930.98 & 6.86 \\
\hline 05 & Structural & 50.01 & 3,97 & 1173.15 & 13.42 \\
\hline 06 & Structural & 89.12 & 3.37 & 2073.25 & 18.85 \\
\hline 08 & Structural & 45.84 & 3.12 & 880.30 & 10.20 \\
\hline 09 & Non-structural & 57.93 & 2.88 & 1919.15 & 9.59 \\
\hline 10 & Non-structural & 55.07 & 6.84 & 1636.73 & 21.41 \\
\hline
\end{tabular}

The blocks from producer 04 present the smallest dispersion; the blocks from producer 03 experienced the 
highest material loss; and the blocks from producers 02, 04 and 07 experienced the smallest material loss with smaller volume losses of $1000 \mathrm{~mm}^{3}$.

\subsection{Wet and dry cycle test}

The wet and dry cycle test results after the six cycles are presented in Table 5.

Table 5: Wet and dry cycle test results.

\begin{tabular}{|c|c|c|c|c|c|}
\hline \multirow[b]{2}{*}{ Producer } & \multirow[b]{2}{*}{ Block type } & \multirow[b]{2}{*}{ Volume (\%) } & \multicolumn{3}{|c|}{ Mass } \\
\hline & & & $\begin{array}{c}\text { Average } \\
(\%)\end{array}$ & $\begin{array}{c}\text { Standard } \\
\text { Deviation }\end{array}$ & Variance \\
\hline 01 & Structural & 0.16 & -0.0006 & 0.00126 & $1.57797 \mathrm{E}-06$ \\
\hline 02 & Structural & 0.07 & -0.1072 & 0.02158 & 0.00046553 \\
\hline 03 & Structural & -0.23 & -0.0432 & 0.02158 & 0.00046553 \\
\hline 04 & Structural & 0.17 & -0.0250 & 0.00105 & $1.11083 \mathrm{E}-06$ \\
\hline 05 & Structural & 0.68 & -0.0209 & 0.04259 & 0.001814103 \\
\hline 06 & Structural & -0.30 & 0.0528 & 0.00624 & $3.88877 \mathrm{E}-05$ \\
\hline 07 & Structural & 0.35 & -0.0602 & 0.00128 & 1.63739E-06 \\
\hline 08 & Non-structural & 0.28 & 0.0943 & 0.01463 & 0.000214125 \\
\hline 09 & Non-structural & -0.81 & 0.0218 & 0.00664 & 4.41056E-05 \\
\hline 10 & Non-structural & -0.49 & -0.0092 & 0.00424 & $1.80085 \mathrm{E}-05$ \\
\hline
\end{tabular}

The standard deviation and variance show some regularity. The results of tests that simulate the conditions of the environment (for example wet and dry cycle test) are satisfactory because mass reduction is observed in $70 \%$ of the tested blocks.

Specimens CP2 and CP3 from producers 06 and 08 experienced higher mass variation than the blocks from the other producers when comparing the masses before the beginning of the cycles and after the cycles, and this fact may have been influenced by the average dimension variation for the blocks of these producers.

The blocks from producers 03, 06, 09 and 10 experienced an average expansion while the blocks from the other producers experienced an average shrinkage. It seems that there is no relationship between mass reduction and volume shrinkage because the blocks from producers 03 and 10 experienced mass reduction but block expansion while the blocks from producer 08 experience mass expansion but block shrinkage.

Some blocks experienced a small increase in weight after the wet and dry cycles, which may be explained by the water absorbed by the block. This water is released at temperatures around $160^{\circ} \mathrm{C}$ but the test was carried out in the range of $105^{\circ} \pm 5^{\circ}$.

All blocks experienced only a very small variation both in the mass and volume, which may indicate that the blocks will most likely not have a durability problem. The results obtained herein are smaller than those obtained when cement soil blocks [37, 38] and others type of ceramic blocks [39]. For soil-cement specimens, NBR 13554 allow variations up to $10 \%$, which is considerably greater than the results obtained for the clay blocks.

\subsection{Compressive strength test}

The results of the compressive tests using the gross and net area, the standard deviations, as well as the relationship between the gross area and the net area for each producer are presented in Table 6. 
Table 6: Compressive strength.

\begin{tabular}{c|c|c|c|c|c|c}
\hline \multirow{2}{*}{ Producer } & \multirow{2}{*}{ Block type } & \multicolumn{2}{|c|}{ Gross Area (MPa) } & \multicolumn{2}{c|}{ Net Area (MPa) } & \multirow{2}{*}{ Gross Area/Net } \\
\cline { 3 - 6 } & & Average & $\begin{array}{c}\text { Standard } \\
\text { Deviation }\end{array}$ & Average & $\begin{array}{c}\text { Standard } \\
\text { Deviation }\end{array}$ & $\begin{array}{c}\text { Area } \\
(\%)\end{array}$ \\
\hline 01 & Structural & 13.1 & 14.88 & 32.0 & 12.81 & 40.93 \\
\hline 02 & Structural & 14.2 & 10.42 & 30.0 & 10.1 & 47.33 \\
\hline 03 & Structural & 7.3 & 9.72 & 17.9 & 9.05 & 39.10 \\
\hline 04 & Structural & 12.2 & 8.19 & 26.4 & 7.34 & 46.21 \\
\hline 05 & Structural & 12.8 & 9.41 & 32.3 & 9.59 & 39.62 \\
\hline 06 & Structural & 9.9 & 7.17 & 24.1 & 6.97 & 41.07 \\
\hline 07 & Structural & 13.6 & 10.1 & 34.2 & 10.08 & 39.76 \\
\hline 08 & Non-structural & 5.3 & 13.96 & 23.3 & 11.75 & 22.74 \\
\hline 09 & Non-structural & 2.6 & 26.15 & 15.0 & 21.66 & 17.33 \\
\hline 10 & Non-structural & 5.9 & 33.89 & 17.8 & 23.03 & 33.14 \\
\hline
\end{tabular}

There is a large dispersion in the results but the blocks from producers 03, 06, 08 and 09 have lower dispersion values. All tested structural blocks, of all producers, have compressive strengths calculated using gross area above $6 \mathrm{MPa}$ and all non-structural blocks have compressive strengths above $2 \mathrm{MPa}$; these are higher than the recommended by ABNT NBR 15270 which are $3 \mathrm{MPa}$ for structural blocks and $1.5 \mathrm{MPa}$ for nonstructural blocks. These results can also be seen in Figure 5.

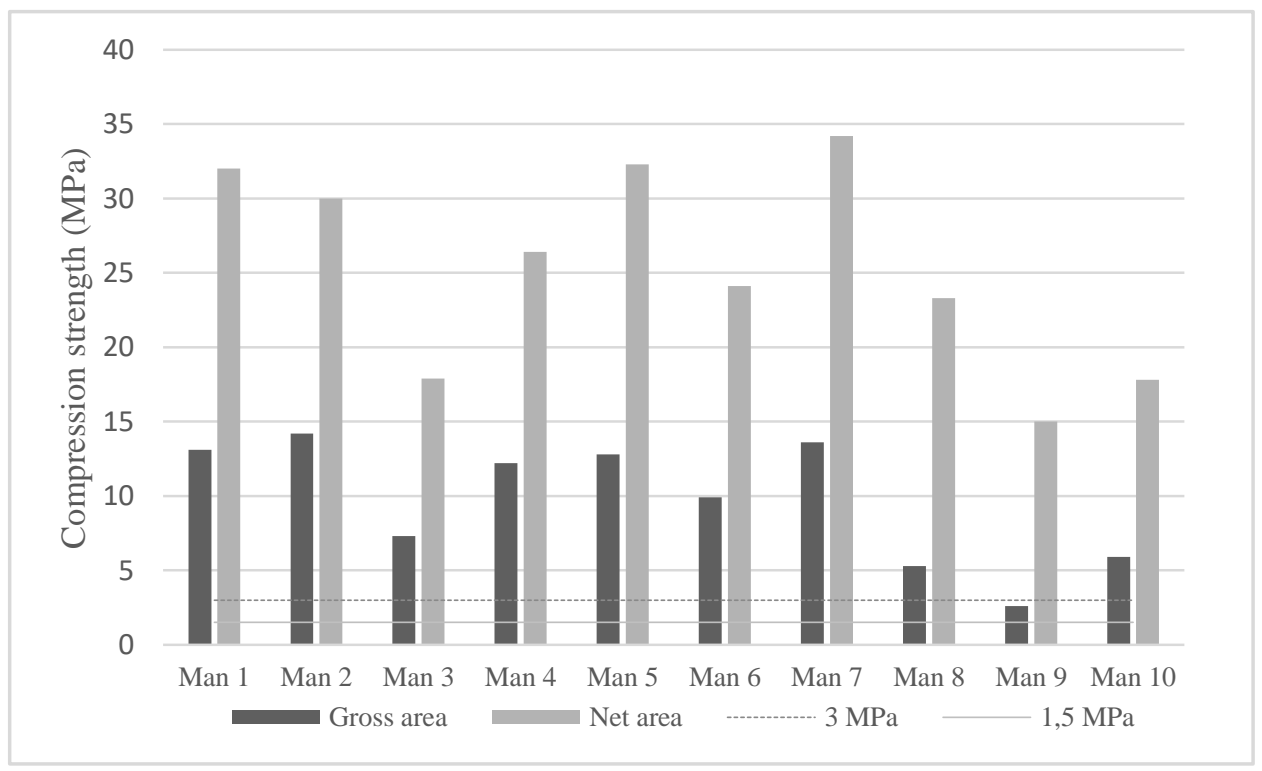

Figure 5: Compression strength: gross area vs area net

The structural blocks from producers 01 to 07 have gross to net area ratio between 39.10 and 47.33 , while non-structural blocks from producers 08,09 and 10 have gross to net area ratio between 17.33 and 33.14.

\subsection{Relationship between test results}

The results did not yield any direct relationship between efflorescence, initial water absorption, and total water absorption, as the blocks from producers 02,06 and 10 did not experience any efflorescence and neither higher rates of total water absorption nor initial water absorption were observed.

ISO 13006 [40] standard for extruded ceramic parts without paraffin coating establishes absorption ranges and relates them to abrasion resistance and compressive strength. The standard presents limit values for each 
of these parameters, where greater compressive strength translates into greater abrasion resistance. For cases where absorption is greater than $10 \%$, the maximum loss should not exceed $2,365 \mathrm{~mm}^{3}$.

From the results presented in tables 2, 4 and 6, the blocks from 9 producers have water absorption higher than $10 \%$, and of these, only blocks from producer 03 had $22 \%$ absorption and a loss greater than $2.365 \mathrm{~mm}^{3}$. Only the blocks from producer 08 had an absorption of less than $10 \%$ and greater than $6 \%$, the blocks from this producer had a volume loss of $1.919,5 \mathrm{~mm}^{3}$, which is lower than that established by ISO 13006 . The blocks from the other producers presented a level of material loss below the limit established by the ISO standard and could therefore be considered more durable blocks.

The relationships among abrasion resistance, compressive strength calculated using the net area, and initial absorption index are shown in Figure 6. These results appear to indicate that there is no proportionality relationship between these properties.

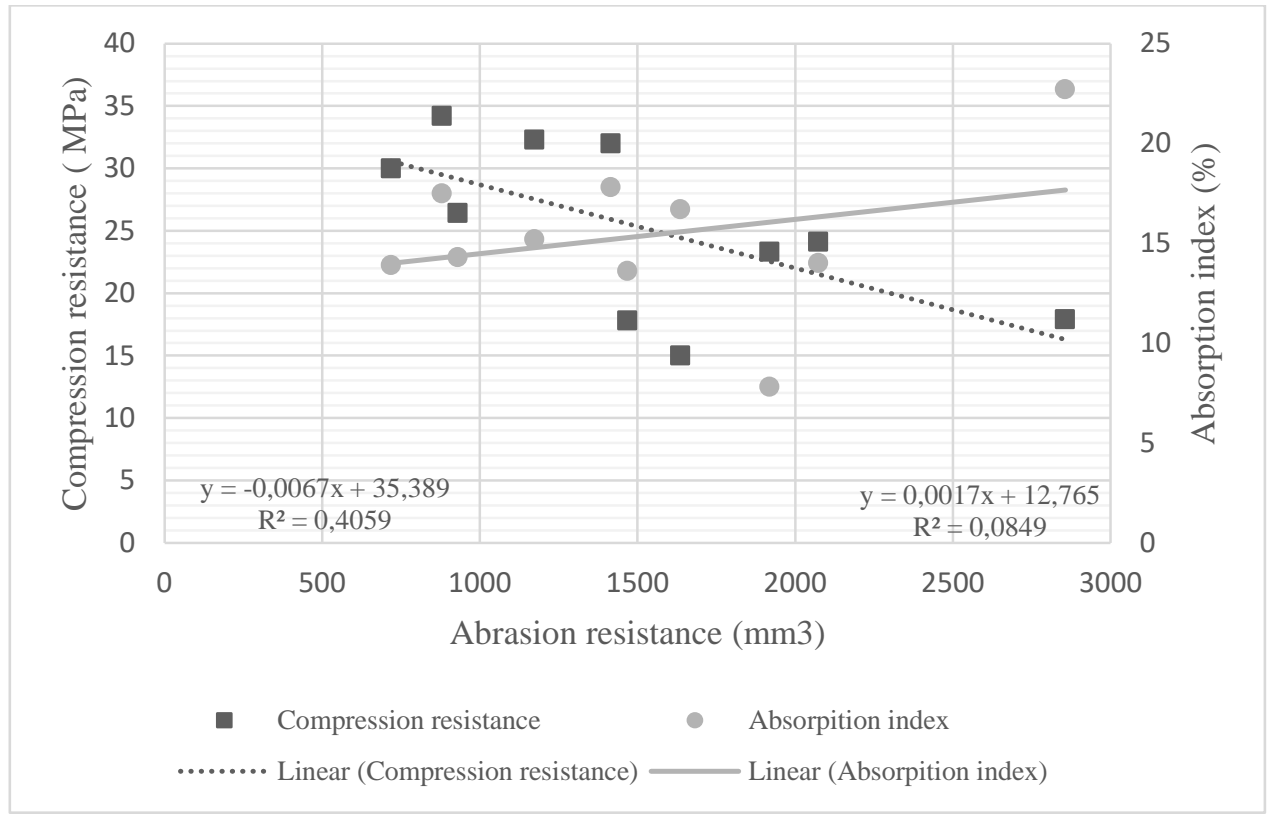

Figure 6: Relationship between abrasion resistance vs compression vs absorption.

An statistical analysis was conducted to verify the linear correlation among the results of these tests and a relationship among them was observed, especially between abrasion resistance and compressive strength, with a correlation coefficient calculated at $-0,6371$, which indicates that the closer to -1 or 1 the greater the trend of linear correlation between the results analyzed, as shown in Figure 7.

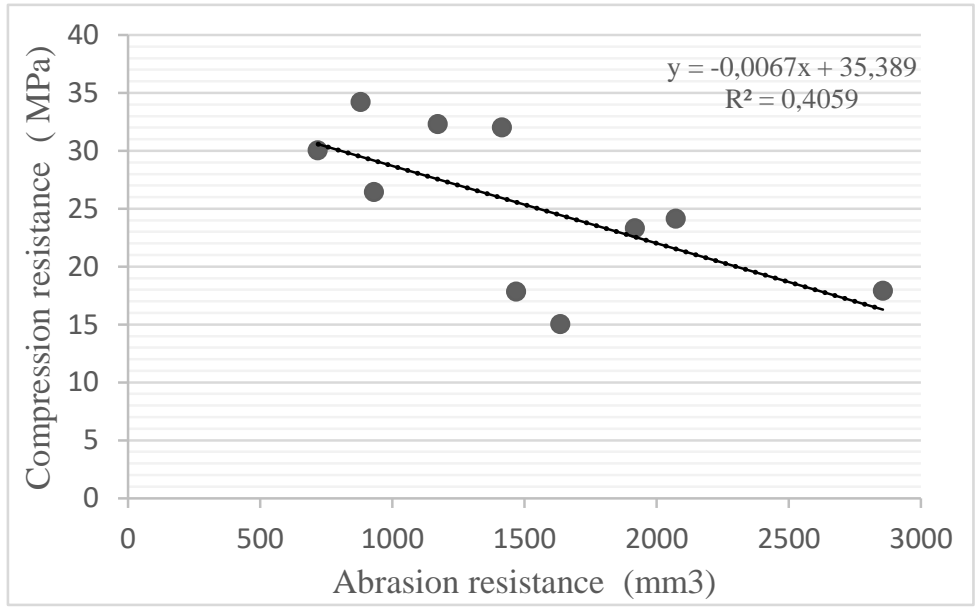

Figure 7 - Relationship between abrasion resistance vs compression. 
The value tending to - 1 means that the graph of resistance to abrasion vs resistance to compression will be closer to a straight line, showing the inversely proportional relationship between these two variables.

For blocks with absorption greater than $10 \%$, a direct relationship between abrasion resistance and absorption index and an inverse relationship between abrasion resistance and compressive strength were observed.

A strong relationship was also observed between the initial absorption index and mass loss, obtained from the wet and dry cycle test, with a linear correlation coefficient of 0,7345. This relationship is presented in Figure 8. The results show that the higher the initial absorption index, the smaller the percentage ratio of mass loss.

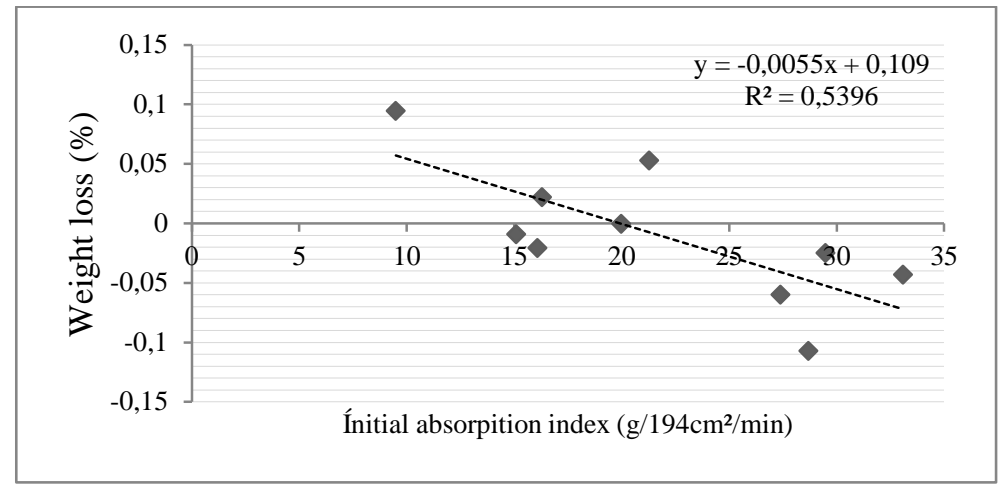

Figure 8 - Relationship between initial absorption x mass loss.

The density results with and without paraffin had a stronger relationship with the total absorption index than with the initial absorption. It was observed that blocks with higher absorption levels have lower densities and blocks with lower absorption levels have higher densities, as shown in Figure 9.

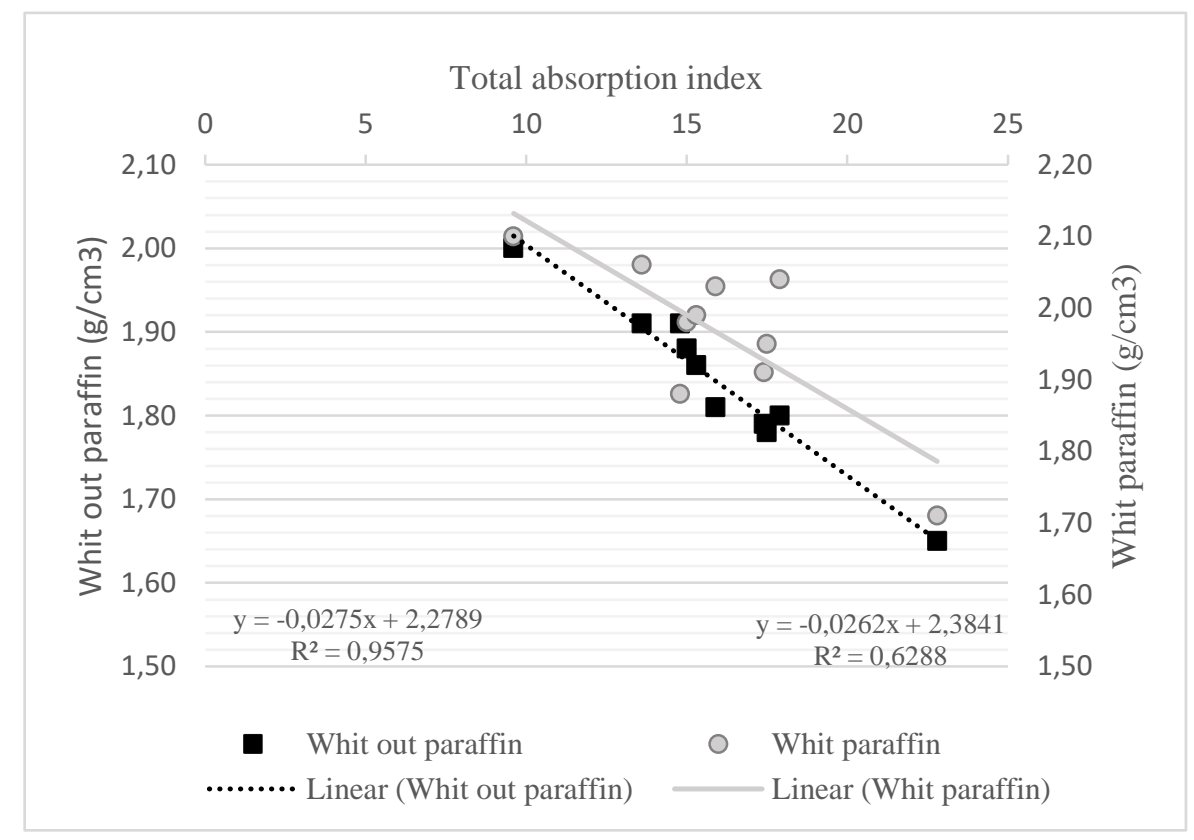

Figure 9: Relationship between total absorption index vs whit out paraffin and whit paraffin.

The same behavior was observed in relationship with initial absorption; i.e., blocks with higher densities have lower initial absorption levels and blocks with lower densities have lower initial absorption levels, as shown in Figure 10. 


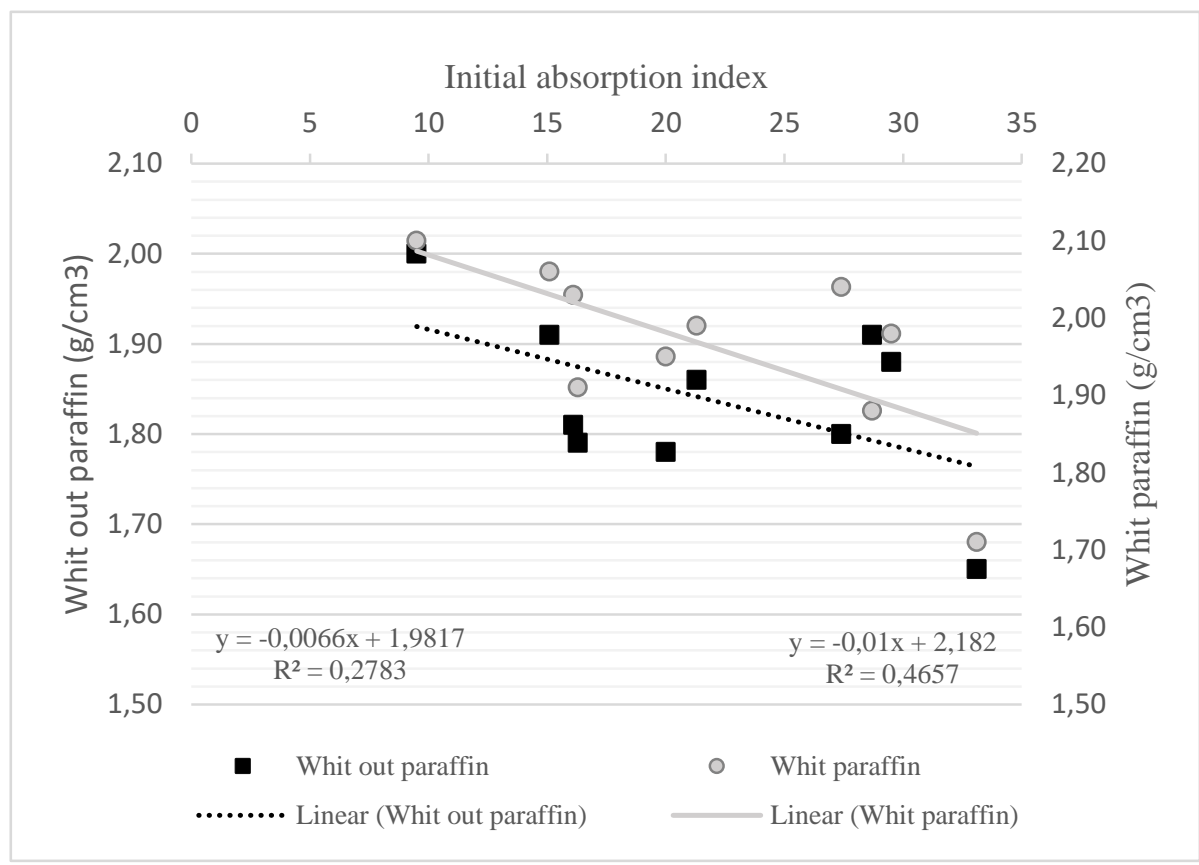

Figure 10: Relationship between initial absorption index vs whit out paraffin and whit paraffin.

\section{CONCLUSIONS}

The results indicate that the total absorption tests in both cold and hot water did not present significant statistical differences for $55.5 \%$ of the cases, with $95 \%$ confidence. This result maybe an indication that the microstructure of the blocks influenced the result, and this is a characteristic of Brazilian ceramic blocks.

Saturation coefficients close to 1.0 were obtained for most blocks, with the lowest value equal to 0.81 . This indicates that those blocks are not suitable for cold regions (subject to freezing, not frequent in Brazil) as they may experience low durability under such environment. On the other hand, it validates the idea of similar results from the cold and from the hot water test methods (for the block types here presented). Blocks with higher absorption are probably blocks with more pores, with a larger apparent volume.

Based on the results presented, a maximum absorption value of uncoated ceramic blocks should be $18 \%$. Because, all the blocks, up to this limit, presented abrasion resistance lower than that specified in ISO 13006.

Density tests with and without paraffin are statistically different. Although the paraffin-free density test is easier to conduct, the paraffin test yielded different results, and the density of the blocks ranged from 1.78 to $2.00 \mathrm{~g} / \mathrm{cm} 3$. The results of the paraffin density test are related to the water absorption values of the blocks, where the blocks with higher water absorption have lower density values. The paraffin results are higher than the paraffin-free results and should be considered more realist as the material is sealed while immerged into water. The paraffin-test is now specified in the ABNT NBR 15270.

The ASTM C67 efflorescence test is simpler to conduct and more efficient than the simplified method suggested by Franco, although it may yield reliable results if adjusted to its methodology. The results confirm that efflorescence is not related to any of the water absorption indexes.

The wet and dry cycle test yielded satisfactory results. Thus, the test may simulate the conditions of the environment in which the ceramic blocks experience. Further testing shall be done considering this hypothesis.

There is an inverse relationship between the initial absorption index and mass loss, where the higher the initial absorption index the lower the mass loss. Similar relationship exists between absorption in cold or hot water and mass loss, howbeit, slightly stronger for absorption in cold water.

The all structural blocks presented compressive strengths using the gross area above $6 \mathrm{MPa}$, no matter the producer and producer-region. This shall induce producers to recommend the minimum 6-MPa strength for structural block specification although the current ABNT NBR 15270 allows lower values. 


\section{ACKNOWLEDGMENT}

The authors of this paper are grateful for the participation of the National Ceramic Industry Association ANICER, for making this research possible.

\section{REFERENCES}

[1] CALLISTER Jr, W.D., RETHWISCH, D.G., Ciência e Engenharia de Materiais: Uma Introdução,9a ed. Rio de Janeiro, LTC, 2016.

[2] MATENCIO, T., "Importância dos materiais cerâmicos em nossa sociedade", Revista Matéria, v.25, n.1, 2020.

[3] OTITOJU, A., "Advanced ceramic components: Materials, fabrication, and applications", J. Ind. Eng., v.85, pp. 34-65, 2020.

[4] ANICER, Associação Nacional da Industria Cerâmica (ANICER). Dados online, Rio de Janeiro, Retrieved from: www.anicer.com.br/anicer/setor, 2019.

[5] ROMAN, H.R., MOHAMAD, G., Alvenaria estrutural - classificação e materiais, Florianópolis. EduUFSC, 1999.

[6] HENDRY, A.W., KHALAF, F.M., Masonry wall construction. London: Spon Press, 2000.

[7] PARSEKIAN, G.A., HAMID, A.A., DRYSDALE, R.G., Comportamento e dimensionamento de alvenaria estrutural, São Carlos, Edufscar, 2013.

[8] GRIDI-BENNADJI, F., CHATEIGNER, D., Di VITA, G., et al. "Mechanical properties of textured ceramics from muscovite-kaolinite alternate layers", Journal of the European Ceramic Society, v. 29, n. 11, pp. 2177-2184, 2009.

[9] BARNES, G.E., "Workability of clay mixtures", Applied Clay Science, v. 153, pp. 107-112, 2018.

[10] MOORE, F., "The mechanism of moisture movement in clays with particular reference to drying: a concise review". Trans Brit Ceram Soc., v. 60, pp. 517-539, 1961.

[11] CULTRONEA, G., SEBASTIÁN, E., ELERT, K., et al. "Influence of mineralogy and firing temperature on the porosity of bricks", ECERS 2004, v. 24, pp. 547-564, 2004.

[12] RIBEIRO, M.J., FERREIRA, J.M., LABRINCHA, J.A., "Plastic behavior of different ceramic pastes processed by extrusion", Ceramics International, v. 31, n. 4, pp.515-529, 2005.

[13] FIGUEIRÊDO, J.M.R, SILVA, J.R.S., NEVES, G.A., et al. "Influence of Processing Variables on ClayBased Ceramic Formulations". Materials Research, v. 22, n. 3, 2019.

[14] ABNT NBR 15270, Associação Brasileira de Normas Técnicas (Brazilian Association of Technical Standard), NBR 15270 - Ceramic components - Clay blocks and bricks for masonry Part 2, Test methods, 2017.

[15] ASTM C67, American Society for Testing Materials, ASTM C67 - Standard Methods for Sampling and Testing Brick and Structural Clay Tile, In Annual Book of ASTM, 2014.

[16] The Brick Industry Association, Technical Notes 3A - Brick Masonry Material Properties, Technical Notes on Brick Construction, v. 216 (December), 1992.

[17] PRADO, S., "Resistência a Compressão de Tijolos e Blocos Cerâmicos de Diferentes Formas e Dimensões". MSc Thesis, Federal University of Santa Catarina, Florianópolis, Brazil, 1995.

[18] WITZANY, J., CEJKA, T., SÝKORA, M., et al. "Strength assessment of historic brick masonry", Journal of engineering and management, v, 22, n. 2, pp. 224-233, 2016.

[19] MENDES, R.J.K., "Resistência à Compressão de Alvenarias de Blocos Cerâmicos Estruturais", MSc Thesis, Federal University of Santa Catarina, Florianópolis, Brazil. 1998.

[20] KAUSHIK, H.B., RAI, D.C., JAIN, S.K., "Stress-Strain Characteristics of Clay Brick Masonry under Uniaxial Compression", Journal of Materials in Civil Engineering, v.19, n.9, pp. 728-739, 2007.

[21] RIZZATTI, E.I., ROMAN, H.R., MOHAMAD, G., et al. "Tipologia de blocos cerâmicos estruturais: Influência da geometria dos blocos no comportamento mecânico da alvenaria", Revista Matéria, v.16, n.2, pp. 730-746, 2011

[22] LOSSO, M., VIVEIROS, E.B., "Gesso Acartonado e Isolamento Acústico: Teoria Versus Prática no Brasil", In: Anais da I conferência Latino-Americana de construção sustentável e X Encontro nacional de tecnologia do ambiente construído, pp. 3 - 12, São Paulo, Brasil, 18 a 21 de julho 2004.

[23] DUARTE, E.A.C., VIVEIROS, E.B., "Isolamento Acústico: O Atributo invisível na história da moradia 
brasileira", In: Encontro de conforto no ambiente construído, pp. 605-615, Maceió, Brasil, 05-07 de outubro 2005.

[24] DONDI, M., MAZZANTI, F., PRINCIPI, P., et al. "Thermal Conductivity of Clay Bricks", Journal of Materials in Civil Engineering, v.16, n.1, pp. 8-14, 2004.

[25] ALONSO-SANTURDE, R., ANDRÉS, A., VIGUR, I. Jr., et al. "Technological behavior and recycling potential of spent foundry sands in clay bricks", Journal of Environmental Management, v.92, n.3, pp. 9941002,2011

[26] NCMA, National Concrete Masonry Association, Control and Removal of Efflorescence. NCMA TEK. v.2, n.397, pp. 3-6, 2003.

[27] MENEZES, R.R., FERREIRA, H.S., NEVES, G.A., et al. "Sais solúveis e eflorescência em blocos cerâmicos e outros materiais de construção: revisão". Cerâmica, v.52, n. 321, pp. 37-49, 2006.

[28] CHIN, I.R., BEHIE, B., "Efflorescence: Evaluation of Published Test Methods for Brick and Efforts to Develop a Masonry Assembly Test Method", Journal of ASTM International, v.7, n.5, pp. 1-7, 2010.

[29] BAPTISTA, A., "Procedimentos e resultados de ensaios de caracterização física e mecânica de blocos cerâmicos estruturais e de vedação", MSc Thesis, Federal University of São Carlos, São Carlos, Brazil, 2018.

[30] ABNT NBR 10838, Associação Brasileira de Normas Técnicas (Brazilian Association of Technical Standard). NBR 13838 - Soils — Determination of specific gravity of undisturbed samples — Hydrostatic balance - of test, 1988 .

[31] FRANCO, L.S., "Projeto de revestimento de fachadas - Ensaio de avaliação de eflorescência de componentes cerâmicos", ARCO - Assessoria em Racionalização Construtiva, pp. 1-5, 2012.

[32] ABNT NBR 13818, Associação Brasileira de Normas Técnicas. (Brazilian Association of Technical Standard), NBR 13818 - Ceramic tiles - Specification and methods of test, 1997.

[33] ABNT NBR 13554, Associação Brasileira de Normas Técnicas. (Brazilian Association of Technical Standard), NBR 13554 - Soil-cement — Durability test by wetting and drying — Test method, 2012.

[34] CSA, Canadian Standard Association, CSA-A82.1-M87. Burned Clay Brick (Solid Masonry Units Made from Clay or Shale). 1987.

[35] DRYSDALE, R.G., HAMID, A.A., BAKER, L.R., Masonry Structures: Behavior and Design. New Jersey, Prentice Hall, 1994.

[36] GROOT, C., LARBI, J., "The influence of water flow (reversal) on bond strength development in young masonry", Heron, v.44, n.2, pp. 63-78, 1999.

[37] CARVAlHO, A., XAVIER, G.C., ALEXANDRE, J., et al. "Environmental Durability of Soil-Cement Block Incorporated with Ornamental Stone Waste", Materials Science Forum, v.798-799, pp. 548-553, 2014.

[38] FRANÇA, B.R., AZEVEDO, A.R.G., MONTEIRO, S.N., et al. "Durability of Soil-Cement Blocks with the Incorporation of Limestone Residues from the Processing of Marble", Materials Research, v. 21, Suppl. 1, 2018.

[39] PEDROTI, L.G., "Estudo de conformidades em relação à ABNT de blocos cerâmicos prensados e queimados", MSc Thesis, Universidade Estadual do Norte Fluminense, Campos dos Goytacazes (RJ), Brasil, 2007.

[40] ISO 13006, ISO - International Organization for Standardization. Ceramic tiles - Definitions, classification, characteristics and marking, 2018.

\section{ORCID}

Ailton Soares Freire

https://orcid.org/0000-0002-5305-1157

Adriana Cristina Morais Baptista

https://orcid.org/0000-0003-1977-4703

Guilherme Aris Parsekian

https://orcid.org/0000-0002-5939-2032

Fernando Soares Fonseca

https://orcid.org/0000-0002-8945-8696 